\title{
Semiarid ethnoagroforestry management: Tajos in the Sierra Gorda, Guanajuato, Mexico
}

\author{
Vincent M. Hoogesteger van Dijk', Alejandro Casas $^{1}$ and Ana Isabel Moreno-Calles ${ }^{2^{*}}$ (D)
}

\begin{abstract}
Background: The semi-arid environments harbor nearly $40 \%$ of biodiversity, and half of indigenous cultures of Mexico. Thousands of communities settled in these areas depend on agriculture and using wild biodiversity for their subsistence. Water, soil, and biodiversity management strategies are therefore crucial for people's life. The tajos, from Sierra Gorda, are important, poorly studied, biocultural systems established in narrow, arid alluvial valleys. The systems are constructed with stone-walls for capturing sediments, gradually creating fertile soils in terraces suitable for agriculture in places where it would not be possible. We analyzed biocultural, ecological, economic and technological relevance of the artificial oasis-like tajos, hypothesizing their high capacity for maintaining agricultural and wild biodiversity while providing resources to people.

Methods: We conducted our research in three sections of the Mezquital-Xichú River, in three communities of Guanajuato, Mexico. Agroforestry management practices were documented through semi-structured and in-depth qualitative interviews. Vegetation composition of local forests and that maintained in tajos was sampled and compared.

Results: Tajos harbor high agrobiodiversity, including native varieties of maize and beans, seven secondary crops, 47 native and 25 introduced perennial plant species. Perennial plants cover on average $26.8 \%$ of the total surface of plots. Tajos provide nearly $70 \%$ of the products required by households' subsistence and are part of their cultural identity.

Conclusions: Tajos are heritage of TEK and land management forms of pre-Columbian Mexican and Mediterranean agricultural techniques, adapting and integrating modern agricultural practices. Tajos are valuable biocultural systems adapted to local semiarid conditions and sources of technology for similar areas of the World.
\end{abstract}

Keywords: Agrobiodiversity, Arid zones, Biocultural heritage, Mesoamerica, TEK

\section{Background}

Steep slopes, severe long dry seasons, low rainfall, scarce plant cover, and shallow soils are common features of landscape dry areas of Mexico, a Country with nearly $60 \%$ of its territory occurring in arid, semi-arid and subhumid environments. These areas, however, lodge about $40 \%$ of the biodiversity of the country and most endemic species [1]. In addition, these areas, harbor high human cultural richness, being inhabited by 30 of the 58 main indigenous ethnic groups identified in the country [2]. Thousands of communities settled in arid and semi-arid

\footnotetext{
* Correspondence: isabel_moreno@enesmorelia.unam.mx

¿Escuela Nacional de Estudios Superiores Unidad Morelia, Universidad Nacional Autónoma de México (UNAM), Antigua Carretera a Pátzcuaro 8701, Col. San José de la Huerta, 58190 Morelia, Michoacán, Mexico

Full list of author information is available at the end of the article
}

areas of Mexico depend on agriculture and use of local wild biodiversity for their subsistence [3]. In such context, the construction of water control, irrigation systems and strategies for preserving both water and soils such as the agroforestry terraces that allow favorable farming conditions, have been historically main worries of peoples practicing agriculture in arid lands [4]. Although studies examining peasant agroforestry land management in semiarid lands of Mexico are scarce, some of them have documented that these systems involve management of wildlife and agro-biodiversity. In the arid zones of this country, Altieri and Toledo [5], for instance, described agroforestry terraces belonging to the $\tilde{N} a h \tilde{u} u$ people of the Mezquital Valley, Hidalgo and the Papago communities in the Sonoran Desert showing a 
significant amount of biodiversity management involved in the systems. Our research group conducted studies in the Tehuacán Valley, Puebla with different agroforestry systems (AFS) that associate maize production with columnar cacti, rosetophyllous scrub, chaparral, mesquite, and palm forests handled by Náhuatl, Popoloca, Cuicatec, Mixtec, Ixcatec, and Mestizo peoples of the Tehuacán Valley [6-9]. Also outstanding are the oases managed by people in Baja California $[10,11]$ and the desert gardens in San Luis Potosí [4], and the huamil system in the region of the Valley of Santiago, Guanajuato [12], which associates Opuntia species with maize [13]. The common finding of all these studies is that AFS of arid and semiarid zones provide ecosystem benefits such as refuges for pollinators and seed dispersers, bridges that at landscape and plot level contribute to maintain the regional biodiversity, prevent soil erosion, and maintain water and soil storage. At the same time, AFS contribute to decrease the risk of losing supply of natural resources for satisfying livelihoods. In addition, these systems contribute to form complex and heterogeneous landscapes with high agro-biodiversity, which help to reduce deforestation for establishing new agricultural areas, making easier the conservation and restoration the bio-cultural diversity $[14,15]$.

The tajos, practiced by people of the Sierra Gorda, central Mexico, are highly dynamic and important agroforestry systems that however have been scarcely studied. These AFS involve irrigation and soil management techniques using the ground, sand and organic materials carried by the river, and are specifically designed by local people, according to the surface allowed by the alluvial areas, slope inclination, and other environmental conditions. Tajos are constructed in the lower and arid parts of the mountainous region of the northeastern Sierra Gorda, in the area considered in the past to be the northern boundary of Mesoamerica, just in the frontier with the cultural region called Aridoamerica [16]. Agroforestry and hydraulic management of the river sediments make possible that tajos become land for agriculture where natural conditions do not allow it. This study analyzes the ecological, economic and cultural importance of the tajos in the Sierra de Xichú, Guanajuato, Mexico. We particularly explored the following questions: i) Which are the main wild and domesticated components of tajos, the diversity and composition of perennial plant species, ii) what is the role of tajos in maintaining the household economy of farmers who manage them, and iii) what is the current cultural significance and potential of these forms of AFS management. Our preliminary observations of the systems allowed hypothesizing that these systems maintain significant local biodiversity and are the basis for subsistence of local people.

\section{Methods}

Study area

Tajos are in the municipality of Xichú, Guanajuato, in the mountainous region of the Sierra Gorda, which is part of the Sierra Madre Oriental of Mexico. The physiography of this region is characterized by pronounced mountains forming deep canyons, with semi-arid intermountain valleys, and small alluvial valleys (locally called vegas) on the banks of streams and rivers. There are some plateaus and small areas of hillocks, which are inaccessible for obtaining natural resources. The area still harbors well-conserved natural vegetation that has remained at low impairment [17-19], reason the Mexican Government decreed the Biosphere Reserve Sierra Gorda in February 2007 [20].

The study area includes the rural communities of Organitos, Llanetes, and La Laja (Fig. 1). Organitos is in the upper river area, at an elevation of $1200 \mathrm{~m}$, Llanetes is in the middle part at $930 \mathrm{~m}$ and La Laja is in the lower area $(<900 \mathrm{~m})$. The communities belong to the Ejido Las Ajuntas, conformed by scattered hamlets located mainly on slopes above the floodplain (Fig. 2). The community of Organitos is composed only by 30 households, while La Laja is inhabited by nearly 100 households, according to the local authorities.

Climate of the study area is subtropical dry, semi-arid, influenced by the rain shadow caused by the mountains surrounding the lower parts of the basin, with average annual temperatures from $20{ }^{\circ} \mathrm{C}$ to $29{ }^{\circ} \mathrm{C}$ and annual rainfall varying from 450 to $600 \mathrm{~mm}[17,18]$. Soils are mostly shallow lithosols, except in the agricultural areas of alluvial valleys where these are formed by luvisols resulting from artificial sediment capture [19, 21]. In the study, it is possible to distinguish two environmental units: The alluvial valley formed by the passage of the Mezquital-Xichú River, and the steep slopes and ravines surrounding this valley (Fig. 3).

Local people practice the agriculture of tajos where the original vegetation is gallery forest surrounded by steep and barren slopes and ravines dominated by shallow soils of limestone and vegetation represented mainly by tropical deciduous forest (TDF) and rosetophyllous scrub (RS) $[17,21]$.

\section{Documenting agriculture and agroforestry practices in tajos}

For selecting the study plots we considered that: i) the plots were in the alluvial valleys, had constant or seasonal irrigation through channels with ephemeral diversion dams deliberately constructed for agriculture; ii) the system combined crops with forest components and livestock; iii) the systems were under active management by local traditional people. We carried out in-depth qualitative interviews with farmers who manage the 


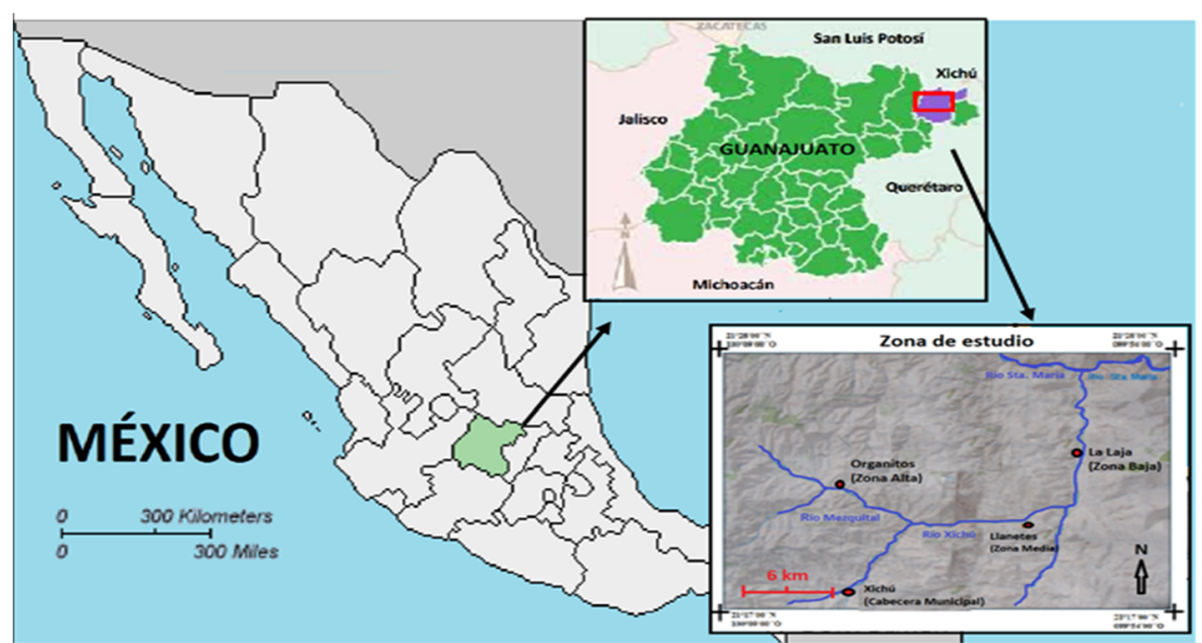

Fig. 1 Study area. Location of the Municipality of the Xichú River, and the communities studied of Llanetes, Organitos and La Laja, in the state of Guanajuato

plots, using methods developed by Moreno-Calles et al. [7] and García-Moya [19].

\section{Vegetation sampling and analyses of plant diversity in the tajos}

We described the plant diversity and structure of the tajos, by using the vegetation sampling method developed by Moreno-Calles et al. [7]. We sampled vegetation in nine plots, three located in each study zone. In each site, we conducted the following activities: (i) Description of the plots, geo-localization, elevation, total area and relative surface of agroforestry practices. (ii) Description of environmental aspects and agricultural management practiced in the plot. (iii) Censuses of perennial vegetation $>1 \mathrm{~m}$ height, recording common and scientific names, and forms of use and management of each species. (iv) Measuring the diameter at breast height (DBH), height and cover of each individual plant. (v) Collecting and preparing of voucher specimens, which were deposited in the Herbarium of the Botanic Garden "El Charco del Ingenio A. C." in San Miguel de Allende, Guanajuato. The percentage of vegetation cover of the plots was calculated through the methods developed by Moreno-Calles et al. [6, 7] using polygons (rectangular, circular and triangular) to estimate the area occupied by perennial vegetation for each type of

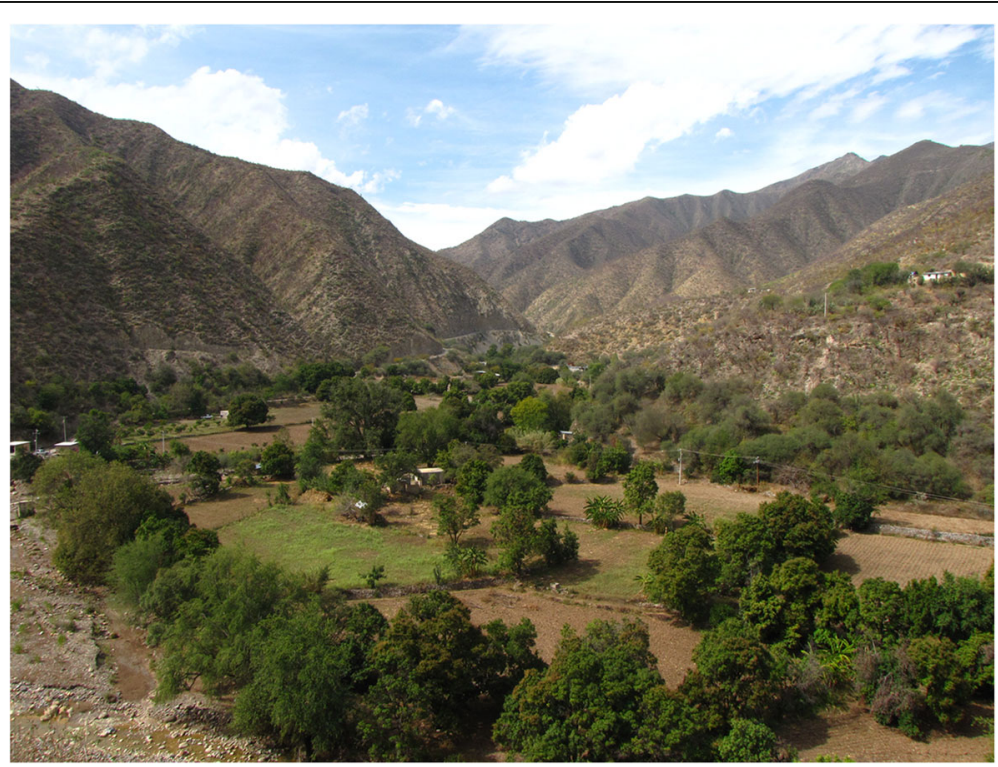

Fig. 2 Photograph illustrating the aspect of the tajos in the study area 


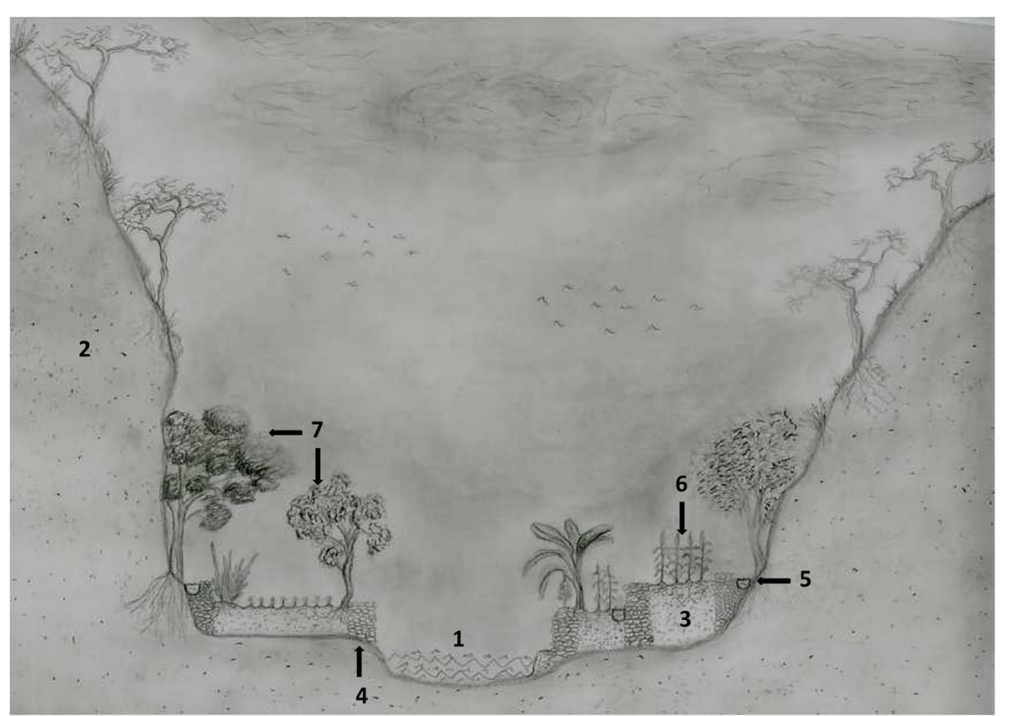

Fig. 3 Profile of the river basin section and the location of tajos describing tajos. 1) River, 2) mountain slope, 3) lamedal, 4) tajos stone-walls, 5) acequias, 6) crops, 7) perennial vegetation

agroforestry practice (calculated by using a GPS) in each sampled plot.

To compare the plant species richness among sampled plots, we built plots using the rarefaction method developed by Gotelli and Colwell [22], using EcoSim700 [23]. The scientific names of plant species were determined according to Martinez [24] and Rzedowski et al. [17]. We standardized the plant nomenclature and authorities by using the International Plant Names Index [25].

\section{Results}

\section{Tajos: concept and construction}

Tajos are deliberate human constructed systems, involving local traditional knowledge and adaptive management of natural resources in small riversides converted into oases surrounded by semiarid landscapes. Such artifices allow practicing agriculture as agroforestry systems. In the communities studied, the term tajo is a polysemic term, often used as a synonym of agricultural plot or as maize-field. The word tajo also, makes specific reference to the stone-wall built for forming terraces near the river. Building tajo plots is a process based on the artificial capture of fertile river sediment (lamedal). The tajos are the only sites that have fertile soils to allow growing agricultural crops in the zone. The river valley areas where tajos are absent, usually are sand beaches exposed to flashfloods, narrow gallery forests or steep cliffs and slopes with very shallow and infertile soils, where it is not possible to carry out agriculture. Building tajos begins with the assessment of the riverbanks and mudflats adequate for its establishment. The places selected should be protected from the river flashfloods during the rainy season, but the protecting barriers should allow the capture and storage of water and sediments by gravity, gradually forming high fields that change the topography and the natural flow of water. Most tajos are directly next to each other, parallel to the main river stream. The plots size is variable, as well as its geographical orientation and its vegetation structure (Fig. 4). The average size of tajos plots was $1.2 \pm 0.95$ ha, but the tendency is that the plot size gradually increases down the river.

The tajos have infrastructural components that are common and essential for their operation. Stone-walls that surround the lower parts of the plot are the main element. These are built on the sandy river beds, using stones from the river most commonly without cement. The foundation walls are constructed with big stones to provide strength and durability to the wall. As the walls rise, people add progressively smaller stones. The main function of the walls is to retain sediments washed down form the higher mountains by the river, which are rich in organic matter, minerals, and nutrients. They also set the limits of the agricultural system with the river or the neighboring plots. The walls progressively elevate their height as the soil profile increases its depth, due to the artificial trapping of lamedal, a process locally called abonar which means fertilizing. The peasants interviewed indicated that depending on the effort invested for constructing the walls and the amount of water the river carries every rainy season, the fertile soil profile might increase from 30 to $80 \mathrm{~cm}$ per year. Consequently, the height of the walls is a reliable indicator of the antiquity of the active management of each plot.

The irrigation channels (locally called acequias) are the structures that carry water and sediments from the 


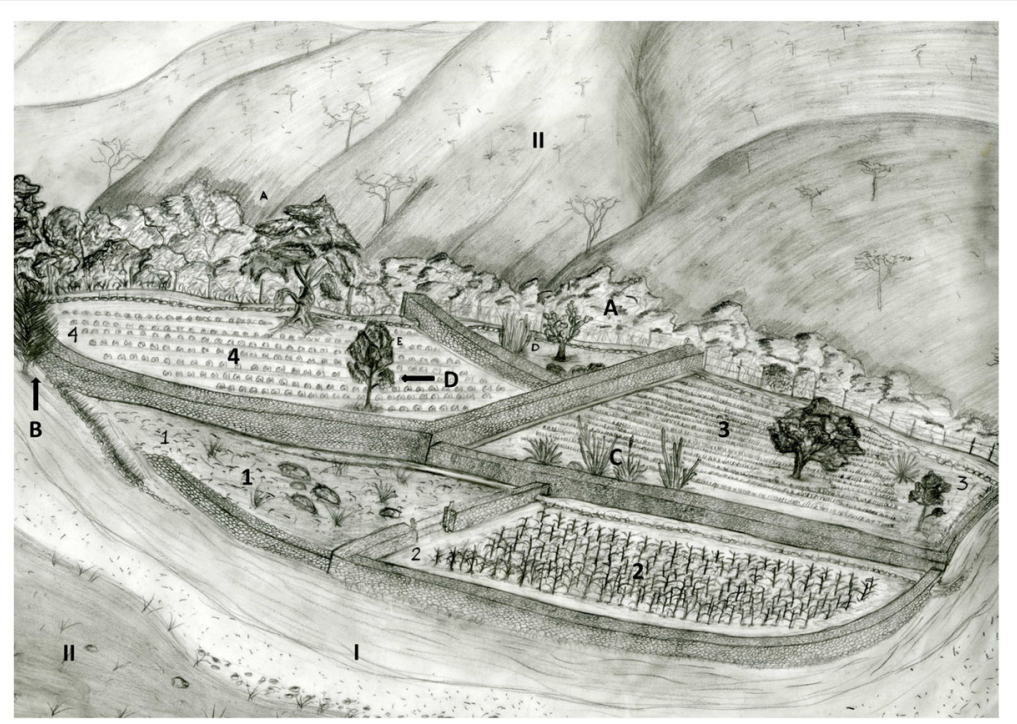

Fig. 4 General scheme of tajos. I) River, II) mountain slope. Sequence of construction of tajos: 1) Stage 1, starting of tajo construction, 2) stage 2, first crops developed, 3) stage 3, older tajos with longer management, 4) stage 4, fully developed tajos with perennial plant species and crops. Perennial vegetation: A) Vegetation near slopes, B) vegetation near riverside, C) vegetation in plot boundaries, D) vegetation isle

river to the farmlands. These are built taking advantage of the natural slope of the alluvial valley by gravity. Channels are commonly constructed by leveling out the steep slopes or digging a depression on the riverbeds, often reinforced with readily available materials such as rocks, logs, branches, and ground obtained on the site. In the steep slopes the acequias are often sustained by stone-walls (sometimes built by using cement) to prevent them from washing away with landslides. Generally, each plot has its own channel, but it is also common to see collective use of these structures constructed, maintained, and shared by several persons working in neighboring plots. The diverter dams, called tomas supply the acequias with streaming water from the river. These dams are built with branches, sticks and stones and covered with sand or gravel, inclined upstream allowing the diversion of water. Some are constructed with stones and cement, but generally these are temporary structures that are destroyed with flashfloods during the rainy season, and require to be rebuilt each agricultural season. To protect the tomas and acequias from flashfloods, water spoilers are often built, and these are locally called cortinas. The cortinas are constructed with various materials outside the acequias, inclined in favor of the stream in a way that allows that the extra water and debris can spill over back into the river. People may also use gates, weirs, and other structures to regulate the volume of water in the channels and exclude objects carried by the river current that may cause damage to other structures. For protecting crops against potential damage from domestic animals (mainly cows, goats and donkeys) the plot boundaries are usually surrounded with fences.
While tajos depend on the river inputs (water and sediments), the river also represents the highest threat to the construction, as periods of extreme rainfall and their resulting flashfloods may cause partial or destruction of the agricultural fields. For instance, many plots were destroyed during extreme rainfall in the Summer of 2005; then, their reconstruction started again. This fact illustrates that tajos are spatially and temporally dynamic, as the landscape in the floodplain changes through time.

\section{Biocultural and agricultural relevance}

The presence of crops in each time depends directly on the availability and abundance of water in the river; therefore, it is possible to register crops of the same species at very different stages at the same time, as well as in different times of the year. Peasants grow three varieties of maize ("white", garambullo and "red") and other agricultural crops like negro enredador beans (Phaseolus vulgaris), chickpeas, the squashes (Cucurbita pepo and C. moschata), the gourds (Lagenaria siceraria), watermelon, peanuts, tomatoes (Solanum lycopersicum and Physalis philadelpyca), the chili peppers (Capsicum annuum), among others. Agricultural products are mainly for direct consumption of local households. When the river has water throughout the year, it is possible to produce three harvests of maize, considering that the local varieties have a ninety days' life cycle. Harvesting maize is carried out once or twice per year, usually sowing chickpeas after harvesting maize. This cultivation pattern results in short fallow periods between agricultural cycles. It is also common to see 
livestock (horses, mules, goats, and cows) free-grazing inside the tajos during fallow periods. Maize is the main crop in the area; the peasant diet and family economy largely depend on it. The cultivation of other species and perennial vegetation management seeks primarily the use of fruits, wood, and firewood. Tilling the land (planting, weeding and fallow) is mainly by using the Egyptian plough, pulled by oxen mules or horses. For optimal development of each agricultural cycle, maize needs three irrigations, one before sowing, a second three weeks after sowing and the third one when it starts to jilotear (producing the female inflorescence), depending on few additional external inputs. The use of fertilizers and agrochemicals was not recorded. There is low use of chemicals to control pests or weeds, often solving problems through manual or biological control means, but some farmers use chemical insecticides and herbicides. There is a common perception among peasants that as time goes by the incidence and number of pests and invasive plant species increases, attributing it to long drought periods, extreme high temperatures and lack of frosts that naturally control the incidence of pests. Among people interviewed, there is consensus that recently there are populations of insects and invasive plants that they did not know or that did not represent damage to crops in the past.

\section{Ecological importance}

Most of the perennial plant species occurring in the tajos are the result of agroforestry practices through three main mechanisms: i) Tolerance or let standing of perennial plants naturally established in the plot; ii) protection against pests, herbivorous excess of humidity, radiation or shade of perennial plants naturally occurring in the plot, and iii) deliberate introduction or propagation (by sexual or asexual means) of native and exotic species. Plant species that have utilitarian or aesthetic value within the local culture are widely tolerated and most of them are native to the ecosystem of the area. The production of fruit, the quality of wood and firewood, the quality of shadow, its contribution to feeding livestock and ornamental value are all qualities that usually influence people to decide toleration of certain plant species in agricultural areas. Several species of native perennial plants are deliberately promoted and protected for utilitarian, aesthetic or cultural values while others are removed because they are inconvenient. We registered seven induced species, nine protected species, many of them being tolerated, and at least four species that are frequently removed (Table 1).

The tajos that we studied had on average $26.8 \%$ of perennial plants cover in relation to its total surface. Strips of vegetation are also in most tajos, as well as scattered trees. The cover of perennial plant species in the tajos depends on: i) growing and propagules production in adjacent plots and slopes; ii) cultivation in the boundaries of the plots close to the river, iii) growing of vegetation in the boundary of the plots with their neighboring plots; iv) maintaining in strips of vegetation within the plots, usually on stone walls; v) growing as isolated trees in plots (Fig. 4). Nearly $45 \%$ of the vegetation cover of plots is commonly located in the adjacencies of the plots, mainly in the slopes, $29 \%$ in the adjacencies of the plots with the river, and about $10 \%$ in the adjacencies between neighboring fields (Figs. 2, 3 and 4).

We recorded a total of 72 perennial plant species, 47 $(65.27 \%)$ of them are native to the local ecosystems while $25(34.72 \%)$ are exotic. In total, 49 genera of 33 different botanical families were identified (Table 2). On average, plots harbor 119 individuals of perennial plants of 18.8 species per hectare. Standardizing its surface, plots have on average $191 \pm 163.77$ perennial individual plants belonging to $40.22 \pm 41.16$ perennial plant species. The rarefaction curve analyses showed that there is a tendency that the amount of perennial plant species decreases down the river (Fig. 5). In the Organitos zone (the higher area) there are expected over 28 plant species, in the Llanetes study are (the middle area) there is an expectancy of 18 species, while in the La Laja study area (the lowest area) only 15 plant species are expected for every 55 recorded individuals (Fig. 5).

\section{Economic and social importance of tajos}

About $70 \%$ of livelihoods of households interviewed depend on the products obtained from the tajos. Communities rely primarily of self-sufficiency agriculture (products for direct consumption of the household), and agricultural products and in smaller proportion of livestock ranching, gathering of wild species and complementary economic activities, primarily migration to urban centers and abroad in search of wage labor or local commerce business. Monetary exchange is rare and happens almost exclusively to acquire the basic products that they do not produce. While local peasants use a wide range of activities in and out of their communities, for most of them agriculture practiced in the tajos remains the main form of obtaining livelihoods and food security for their families throughout the year. Agricultural work is performed in groups with members of the family, by employees or as part of agreements of reciprocity, and solidarity.

Maize and beans (the most common crops) are the products mostly demanded for satisfying the basic needs of local households. Five of the nine farmers interviewed said they were self-sufficient in maize production, requiring between 1.8 to 2 tons of maize per household per year. All peasants, using on average eight to ten bags (60 kg/bag), reach self-sufficiency of beans. The demand 
Table 1 Perennial plant species management in Tajos

\begin{tabular}{|c|c|c|c|}
\hline Management status & Species & Reasons & Management \\
\hline Removed & $\begin{array}{l}\text { Cnidoscolus multilobus } \\
\text { Rhus radicans } \\
\text { Ficus cotinifolia } \\
\text { Pithecellobium dulce }\end{array}$ & $\begin{array}{l}\text { Stinging and competition with } \\
\text { crops }\end{array}$ & $\begin{array}{l}\text { Removed from the surface or root. Cut with an ax or machete, } \\
\text { removed with crowbars or burned }\end{array}$ \\
\hline Tolerated & $\begin{array}{l}\text { Melia azedarach } \\
\text { Acacia farnesiana }\end{array}$ & $\begin{array}{l}\text { They don 't compete with crops } \\
\text { or cause other damage }\end{array}$ & No specific, sometimes inns or partially removed \\
\hline Protected or Encouraged & $\begin{array}{l}\text { Prosopis laevigata } \\
\text { Pithecellobium dulce } \\
\text { Sideroxylon palmeri } \\
\text { Platanus mexicana } \\
\text { Senna atomaria } \\
\text { Morus sp. } \\
\text { Stenocereus pruinosus } \\
\text { Psidium guajava } \\
\text { Carya illinoiensis }\end{array}$ & $\begin{array}{l}\text { Timber, fuelwood, shade, fodder } \\
\text { and fruits for consumption }\end{array}$ & $\begin{array}{l}\text { Protected wild and domestic animals, rising of the river, winds, } \\
\text { drought and extreme temperatures. Pruned and fertilized. } \\
\text { Simply transplanted occasions. }\end{array}$ \\
\hline Cultivated & $\begin{array}{l}\text { Persea americana } \\
\text { Mangifera indica } \\
\text { Citrus spp. } \\
\text { Carya illinoiensis } \\
\text { Musa paradisiaca } \\
\text { Carica papaya } \\
\text { Prunus persica }\end{array}$ & $\begin{array}{l}\text { Fruits for family consumption } \\
\text { and sale }\end{array}$ & $\begin{array}{l}\text { Acquired through exchange or purchase. Propagated seedlings } \\
\text { in home gardens or orchads. Transplanted to privileged sites. } \\
\text { Fertilized, watered, pruned and grafted. }\end{array}$ \\
\hline
\end{tabular}

of products depends largely on the number of members of each family, the needs of each of them and the quantity of livestock they need to feed.

Sporadic cultivation of various secondary crops such as chickpeas, squash, peanuts, tomatoes, green tomato, chili varieties, cultivation of gourds and growing fruits such as avocado and mango aims to self-consumption and small-scale sales within the community. The diversity and abundance of minor crops varies considerably between the plots sampled. Consumption of weedy plants known as quelites (traditional greens) contributes to the diversification and provision of edible biomass and complementary nutriments to the diet of households. Other native plant species are gathered and exploited for medicinal, food, firewood, wood for manufacturing utensils and construction, as well as for animal fodder or for aesthetic and functional values.

\section{Discussion}

Despite the small scale of agricultural land size and the minimum proportion of municipal and regional area, tajos are ethonoagroforestry systems with biocultural, agricultural ecological, and socio-economic relevance like other semiarid agroforestry systems in the country and the World $[5,15]$.

The agricultural relevance involves maintenance of early varieties of maize (3 months) or rainfed crops resistant to drought and other crops varieties, contribute to decrease the risk of losing supply of resources for satisfying livelihoods of the Semiarid Sierra Gorda people and are alternatives of local adaptation in conditions of climatic variability and aridity. In terms of agricultural production, tajos having a wide variety of biodiversity in different temporal and spatial arrangements. Agroforestry practices, crop rotation, producing three crop cycles per year and temporary livestock grazing are examples of this pattern. Tajos artificial construction (crop terraces) for water and soil storage adapting to semiarid and variable regional and local conditions, according to the surface allowed by the alluvial areas, slope inclination, and other environmental conditions similarity in semiarid agroforestry systems in Mexico [4, 6-9, 15]. The local knowledge, practices, agricultural technology, and the associated plant species in the tajos are all elements of the Mesoamerican and pre-Columbian agricultural tradition, combined with many elements of the Mediterranean agricultural tradition introduced by the Spaniards. The irrigation systems accompanied by agricultural terraces allow greater control over the distribution and use of water, and is a feature shared with other pre-Columbian agricultural systems $[4,26]$, which is biocultural and agricultural heritage for semiarid management future.

The Tajos resilience is because, these AFS are highly dynamic temporally and spatially, while gradually built with stones and river sediments, they are vulnerable and recurrently destroyed by the river flashfloods during extreme rainfalls. Therefore, the alluvial valley landscape of these farming systems changes gradually throughout time. They are also adaptable, stable, and resilient over time to the bioclimatic and geomorphological conditions of the area where they are located. The adaptability to these conditions shows that the management of these AFS is the product of a long empirical tradition, which 
Table 2 Perennial species inventory

\begin{tabular}{|c|c|c|c|c|c|}
\hline Family & Species & Local name & Origen & Life form & Uses \\
\hline Agavaceae & Agave sp. & Maguey manso & Introduced & Agave & Sap, Fiber \\
\hline \multirow[t]{3}{*}{ Anacardiaceae } & Mangifera indica L. & Mangoo & Introduced & Tree & Fruit \\
\hline & Rhus radicans $\mathrm{L}$. & Huau & Native & Shrub & Urticante \\
\hline & Spondias mombin Jacq. & Ciruela amarilla & Introduced & Tree & Fruit \\
\hline \multirow[t]{3}{*}{ Asteraceae } & Montanoa sp. & Candela & Native & Shrub & Medicinal \\
\hline & Senecio salignus DC. & Jara amarilla & Native & Shrub & - \\
\hline & Senecio sp. & Jarilla & Native & Shrub & - \\
\hline \multirow[t]{2}{*}{ Boraginaceae } & Cordia boissieri A.D.C. & Trompillo & Native & Tree & Fodder \\
\hline & Heliotropium sp & & Native & Shrub & - \\
\hline \multirow[t]{2}{*}{ Budlejaceae } & Budleja sp. & Tepozán & Native & Tree & - \\
\hline & Budleja sp. & Tepozancillo & Native & Shrub & - \\
\hline Burseraceae & Bursera simaruba Sarg. & Copal & Native & Tree & - \\
\hline \multirow[t]{5}{*}{ Cactaceae } & Isolatocereus dumortieri (Scheidw.) Backeb. & Órgano & Native & Cacti & Fruit/Firewood \\
\hline & Opuntia imbricata (Haw.) DC. & Cardón & Native & Cacti & - \\
\hline & Opuntia sp. & Nopal & Introduced & Cacti & Fruit/vegetable \\
\hline & Myrtillocactus geometrizans Console & Garambullo & Native & Cacti & Fruit \\
\hline & Stenocereus pruinosus (Otto) Buxb. & Pitayo & Native & Cacti & Fruit \\
\hline Caricaceae & Carica papaya L. & Papaya & Introduced & & Fruit \\
\hline \multirow[t]{2}{*}{ Euphorbiaceae } & Croton sp. & Chicharroncillo & Native & Tree & - \\
\hline & Cnidoscolus multilobus (Pax) I.M.Johnst. & - & Native & Shrub & - \\
\hline \multirow[t]{12}{*}{ Fabaceae } & Acacia farnesiana (L.) Willd. & Huizache & Native & Tree & Firewood \\
\hline & Acacia pennatula Benth. & Tepame & Native & Shrub & Firewood \\
\hline & Acacia sp. & Huizachillo & Native & Shrub & Firewood \\
\hline & Desmanthus sp. & Mesquitillo & Native & Shrub & Firewood \\
\hline & $\begin{array}{l}\text { Eysenhardtia polystachya } \\
\text { (Ortega) Sarg. }\end{array}$ & Palo dulce & Native & Tree & Firewood \\
\hline & Lysiloma acapulcense Benth. & Palo arco & Native & Tree & Firewood \\
\hline & Mimosa sp. & Garabatillo & Native & Tree & Firewood \\
\hline & $\begin{array}{l}\text { Pithecellobium dulce } \\
\text { (Roxb.) Benth. }\end{array}$ & Huamúchil & Native & Tree & Fruit \\
\hline & $\begin{array}{l}\text { Prosopis laevigata } \\
\text { (Humb.\& Bonpl. ex Willd.) M.C.Johnst. }\end{array}$ & Mezquite & Native & Tree & Fruit, Firewod, Wood, Fodder, Ornamental \\
\hline & Prosopis sp. & Palo gusano & Native & Tree & Ornato \\
\hline & Senna atomaria (L.) H.S.Irwin \& Barneby & Palo hediondo & Native & Tree & Firewood and shade \\
\hline & Desmodium sp. & - & Native & Shrub & - \\
\hline Juglandaceae & Carya illinoinensis (Wangenh.) K.Koch & Nogal & Introduced & Tree & Fruit \\
\hline Labiatae & Salvia sp. & Salvia & Native & Shrub & Medicinal \\
\hline Lauraceae & Persea americana Mill. & Aguacate & Introduced & Tree & Fruit \\
\hline Malvaceae & Guazuma ulmifolia Wall. & Guazuma & Native & Tree & Firewood/shade \\
\hline Meliaceae & Melia azedarach L. & Paradise tree & Introduced & Tree & Ornamental \\
\hline \multirow[t]{2}{*}{ Moraceae } & Ficus carica L. & Higuera & Introduced & Tree & Fruit \\
\hline & Ficus cotinifolia Kunth & Higuerón & Native & Tree & Ornamental/shadow \\
\hline Musaceae & Musa paradisiaca L. & Platano jamaico & Introduced & Herb & Fruit \\
\hline \multirow[t]{2}{*}{ Myrthaceae } & Psidium guajava L. & Guayabo & Introduced & Tree & Fruit \\
\hline & - & Palo amole & Native & Tree & - \\
\hline
\end{tabular}


Table 2 Perennial species inventory (Continued)

\begin{tabular}{|c|c|c|c|c|c|}
\hline Solanaceae & Solanum sp. & Tomatillo & Native & Shrub & - \\
\hline Platanaceae & Platanus mexicana Torr. & Álamo & Native & Tree & Ornamental/Fruit \\
\hline Poaceae & Arundo donax Georgi. & Carrizo & Introduced & Herb & Handcrafts \\
\hline Rhamnaceae & Karwinskia humboldtianaS. Watson & Sarabullo & Native & Shrub & Toxic \\
\hline \multirow[t]{2}{*}{ Rosaceae } & Prunus domestica Thunb. & Ciruelo & Introduced & Tree & Fruit \\
\hline & Prunus persica (L.) Batsch & Durazno & Introduced & Tree & Fruit \\
\hline Rubiaceae & Coffea arabica L. & Café & Introduced & Shrub & Infusion \\
\hline \multirow[t]{5}{*}{ Rutaceae } & Casimiroa edulis S.Watson & Zapote blanco & Introduced & Tree & Fruit/medicinal \\
\hline & Citrus spp. & Lima & Introduced & Tree & Fruit \\
\hline & & Naranja & Introduced & Tree & Fruit \\
\hline & & Mandarina & Introduced & Tree & Fruit \\
\hline & & Limón real & Introduced & Tree & Fruit \\
\hline Scrophulareaceae & - & - & Native & Shrub & - \\
\hline Simaroubaceae & Dodonaea viscosa Mart. & Olivo & Native & Shrub & Ornamental \\
\hline \multirow[t]{3}{*}{ Ulmaceae } & Celtis pallida Torr. & Granjeno amarillo & Native & Tree & Firewood \\
\hline & Celtis sp. & Palo blanco & Native & Tree & Shadow \\
\hline & Celtis sp. & Granjeno & Native & Tree & - \\
\hline Verbenaceae & Lantana camara L. & Cinco negitos & Native & Shrub & Ornamental \\
\hline Zapotaceae & Sideroxylon palmeri (Rose) T.D.Penn. & Capulín & Native & Tree & Fruit, wood, shade \\
\hline Zygophillaceae & Morkillia mexicana Rose \& Painter & Viuda & Native & Shrub & Ornamental \\
\hline
\end{tabular}

has allowed the practice of agriculture in a geographic area where natural conditions do not allow performing this activity.

Tajos AFS include the deliberate retention of soil, let standing, or introduction of wild trees and other woody perennial plant species to mix them with cultivated or agricultural diversity and soil and water management profitable from ecological perspectives. This pattern of around $30 \%$ of vegetation cover in agricultural plots has been seen in other semiarid regions of Mexico [6-8, 14, 15, 27]. Only nine studies in Mexico providing information about species richness in semiarid agroforestry systems, these studies have emphasized that in arid and semiarid agroforestry

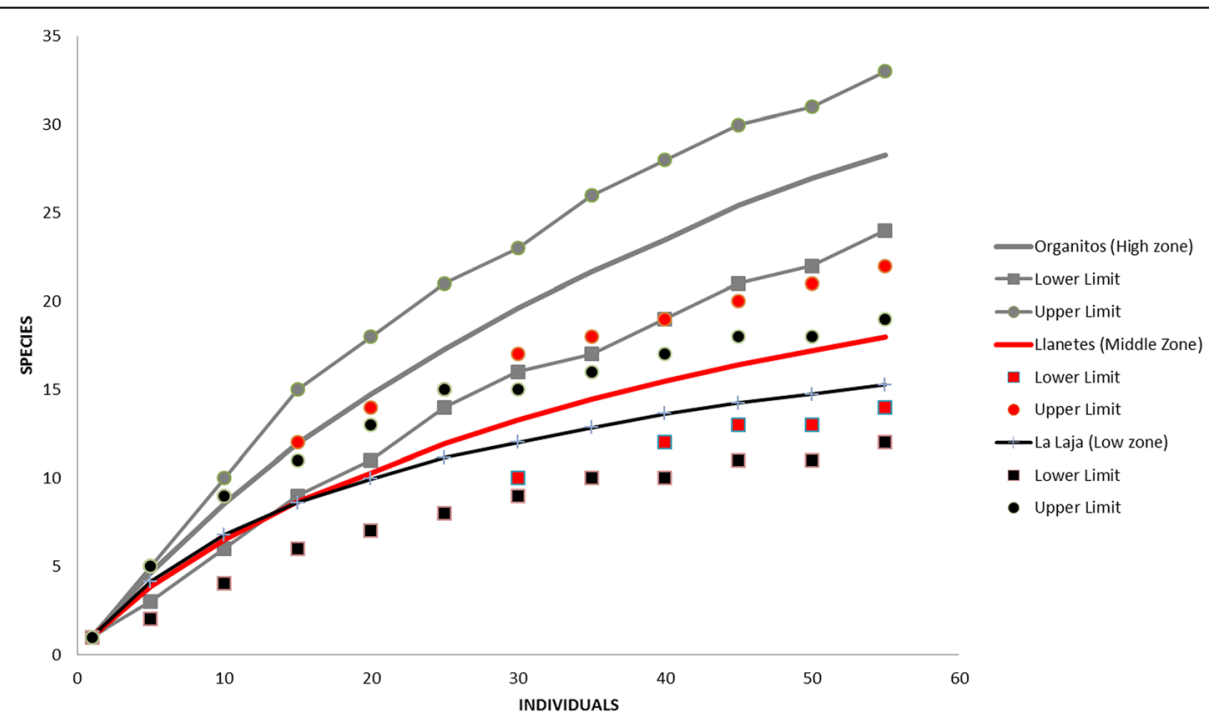

Fig. 5 Rarefaction curves perennial plant species per community. Ratio of number of individuals and number of species expected. Differences between species richness in the upper area with respect to the lower area are observed 
systems people maintain on average $69 \pm 33$ species of plants (SD), $71 \%$ of them native species and in regional reports are $90( \pm 38)$ species [15]. This management provides to the systems to biodiversity at plot and landscape level [28]. Plant diversity can promote the good functionality of the system through better recycling of nutrients, greater resistance to pests and weeds, more efficient resources use, reducing the risk of resources loss, maximizing production and provision of ecosystem services like regulation of local microclimates, hydrological processes, pest control and pollination, issues that should be addressed in future studies [29]. The management of introduced and exotic plant species also contributes to increase biodiversity at the regional level, although most of the introduced elements are only occurring in the tajos.

Besides being the backbone of productive activities, tajos are key elements in the human cultural reproduction of local peasants. Within and around this agro-ecosystem, there is a large body of knowledge, practices and agricultural traditions that are a living sample of peasant culture of these communities. Around building and maintaining tajos, ditches and other elements of these systems, there is a huge wealth of traditional knowledge that depend on the permanence of these practices to survive and be transmitted to subsequent generations. Nature, culture and production are inseparable aspects that allow the construction of local knowledge, being the set of biotic (agro-biodiversity and associated) and abiotic (structures, tools and technologies) elements that are expressed in these AFS those who keep alive the tradition and cultural essence of the local people [30-32].

As in other regions of the warm-dry tropics, in tajos the key factor for growing crops is the water supply. There is a widespread notion among local people that the weather conditions have changed recently becoming extreme, causing longer drought periods and extreme warm temperatures that have complicated farming. Regional climate change, which affects water availability and increases the number of pests and invasive species, is the greatest threat to these traditional AFS and food security. The deterioration of vegetation cover and ecosystem functions and processes in the watershed and its area of influence, especially the loss and degradation of the temperate forests of the upper part of the mountains, could be the main cause of the greatest regional climate change and desertification processes in the study area than global climate change. Therefore, the future of tajos depends primarily on the adequate management and conservation of vegetation cover and forest areas of the mountains of the region, ensuring continuity of the ecological processes in the river basin and the provision of environmental services that result. The general loss of interest among young people in agricultural practices and the consequent aging of farmers threaten the loss of traditional farming knowledge. Promotion of information about benefits and incentives to regional agricultural production as part of public policies are therefore crucial for maintaining these ancient AFS.

\section{Conclusions}

The tajos of the Sierra Gorda of Guanajuato are traditional AFS that withhold a great knowledge, techniques of management and use of local natural resources. The tajos are a kind of fertile artificial oases in the middle of extremely rugged and semi-arid areas where under natural conditions the practice of agriculture is impossible. With minimal use of chemical inputs, they are considerably productive, have a highly-diversified production because of hosting large agro-biodiversity and a great potential for in situ conservation of native perennial plant species, as well as local varieties of annual crops. They are the main source of economic livelihood of rural families and the backbone of the cultural identity of the communities of the region. The deterioration of ecosystems and the consequent climate change at regional and global scale, which has caused the gradual desertification and increased extreme weather events, as well as the accelerated process of acculturation, leading to the abandonment of agricultural practices and knowledge, are the main threats to tajos agriculture. The technological experience of tajos constitutes a valuable source of practices and techniques valuable for other similar arid regions of the world.

\section{Acknowledgements}

The authors thank the local peasants of Xichú, Guanajuato who made this study possible.

\section{Funding}

The authors acknowledge the support in the design of the study and collection, analysis, and interpretation of data and writing the manuscript of the projects DGAPA-UNAM PAPIIT IN200417 and IA203115. and CONACYT CB project 2013-01-221,800.

\section{Availability of data and materials}

Don't applicable.

\section{Authors' contributions}

$\mathrm{VH}$ is the main author. He contributed to the development of this project from its inception to the writing of this report, through planning, fieldwork, interviews and data analysis. AIMC and AC are of the thesis research project. All authors read and approved the final manuscript.

\section{Author's information}

$\mathrm{VH}$ is Environmental Sciences Professional. AC is full time researcher at Instituto de Investigaciones en Ecosistemas y Sustentabilidad, UNAM. AIMC is full profesorresearcher at the Escuela Nacional de Estudios Superiores, Morelia, UNAM.

\section{Competing interests}

The authors declare that they have no competing interests. 


\section{Consent for publication}

The people interviewed were informed about the study's objectives and the eventual publication of the information gathered, and they were assured that the informants' identities would remain undisclosed.

\section{Ethics approval and consent to participate}

The authors asked for permission from the local authorities and the people interviewed to carry out the study.

\section{Author details}

'Instituto de Investigaciones en Ecosistemas y Sustentabilidad, Universidad Nacional Autónoma de México (UNAM), Antigua Carretera a Pátzcuaro 8701, Col. San José de la Huerta, 58190 Morelia, Michoacán, Mexico. ${ }^{2}$ Escuela Nacional de Estudios Superiores Unidad Morelia, Universidad Nacional Autónoma de México (UNAM), Antigua Carretera a Pátzcuaro 8701, Col. San José de la Huerta, 58190 Morelia, Michoacán, Mexico.

\section{Received: 21 November 2016 Accepted: 29 May 2017}

\section{Published online: 12 June 2017}

\section{References}

1. Rzedowski J. Diversity and origins of the phanerogamic flora of Mexico. In: Ramamoorthy TP, Bye RA, Lot A, Fa JE, editors. Biological Diversity of Mexico: Origins and Distribution. New York: Oxford University Press; 1993. p. 129-44.

2. Toledo VM, Ordóñez MJ. The biodiversity scenario of México: a review of terrestrial habitats. In: Ramamoorthy TP, Bye RA, Lot A, Fa JE, editors. Biological Diversity of Mexico: Origins and Distribution. New York: Oxford University Press; 1993. p. 129-44.

3. Casas A, Valiente-Banuet A, Solís L, Pérez-Negrón E. El manejo de la biodiversidad en el desierto: El Valle de Tehuacán-Cuicatlán. In: Toledo VM, editor. La Biodiversidad de México. México City: Fondo de Cultura Económica; 2010

4. Fortanelli J, Loza J, Carlín F, Aguirre Rivera JR. Jardines en el desierto: Agricultura de riego, tradicional y moderna en el altiplano potosino. San Luis Potosí: Instituto de Investigación en Zonas Desérticas, Universidad Autónoma de San Luis Potosí, Consejo Potosino de Ciencia y Tecnología, Gobierno del Estado de San Luis Potosí; 2007.

5. Altieri MA, Toledo VM. Natural resources management among small-scale farmers in semiarid lands: building on traditional knowledge and agroecology. Ann Arid Zone. 2005;44:365-85.

6. Moreno-Calles Al, Casas A, Blancas J, Torres I, Rangel-Landa S, Pérez NE, et al. Agroforestry systems and biodiversity conservation in arid zones: the case of the Tehuacán Cuicatlán Valley, Central México. Agrofor Syst. 2010;80: 315-31

7. Moreno-Calles Al, Casas A, Torres I, García-Frapolli E. Traditional agroforestry systems of multi-crop "milpa" and "chichipera" cactus forest in the arid Tehuacán Valley, Mexico: their management and role in people's subsistence. Agrofor Syst. 2012:84:207-26.

8. Vallejo-Ramos M, Casas A, Pérez-Negrón E, Moreno-Calles Al, HernándezOrdoñez $\mathrm{O}$, Téllez $\mathrm{O}$, et al. Agroforestry systems of the lowland alluvial valleys of the Tehuacán-Cuicatlán Biosphere Reserve: an evaluation of their biocultural capacity. J Ethnobiol Ethnomed. 2015;11:8.

9. Campos N, Casas A, Moreno-Calles Al, Vallejo M. Plant management in agroforestry systems of rosetophyllous forests in the Tehuacán Valley, Mexico. Econ Bot. 2016;70:254-69.

10. Nabhan GO, García J, Routson R, Routson K, Cariño-Olvera M. Desert oases as genetic refugia of heritage crops: persistence of forgotten fruits in the mission orchards of Baja California, Mexico. Int J Biodivers Conserv. 2010;2:56-69.

11. Cariño M, Castorena L, Maya Y, Wurl J, Urciaga J, Breceda A. Transformación de los ecosistemas áridos para su uso agrícola en Baja California Sur. Historia Agraria. 2012;56:81-106.

12. Palerm JV. La persistencia y expansión de sistemas agrícolas tradicionales: El caso del huamil en el Bajío mexicano. Monografías del Jardín Botánico de Córdoba. 1997:5:121-33

13. Colunga-García Marín P. (1984) Variación morfológica, manejo agrícola y grados de domesticación de Opuntia spp. en el Bajío Guanajuatense. Master Thesis. Colegio de Postgraduados, Texcoco.

14. Moreno-Calles Al, Toledo V, Casas A. Los sistemas agroforestales tradicionales de México: Una aproximación biocultural. Bot Sci. 2013;91:375-98.

15. Moreno-Calles Al, Casas A, Rivero-Romero AD, Romero Y, Fisher Ortíz RA, Alvarado F, et al. Ethnoagroforestry: Integration between cultural, forestry and agricultural diversity for sovereignty (food) in Mexico. J Ethnobiol Ethnomed. 2016;12(54):2-21.

16. Lara G. (2002) Aculturación religiosa en Sierra Gorda: El Cristo viejo de Xichú.EHN, México.

17. Rzedowski, J, Calderón de Rzedowski g, \& Galván R. (1996). Nota sobre la vegetación y la flora del noreste del estado de Guanajuato. Flora del Bajío y de Regiones Adyacentes. Fasc. Complementario XIV, México.

18. CONANP, SEMARNAT \& IEEG. Estudio previo justificativo para el establecimiento del área natural protegida "Sierra Gorda de Guanajuato", Guanajuato, México. México: CONANP, SEMARNAT \& IEEG; 2005.

19. García-Moya F. Saber campesino y sostenibilidad agrícola en el noreste de Guanajuato, México. Baeza, Jaén, España: Universidad Internacional de Andalucía, Sede Antonio Machado; 2007.

20. DIARIO OFICIAL DE LA FEDERACIÓN, MÉXICO (2007). Decreto por el que se declara área natural protegida, con el carácter de reserva de la biosfera, la zona conocida como Sierra Gorda de Guanajuato localizada en los municipios de Atarjea, San Luis de la Paz, Santa Catarina, Victoria y Xichú, en el Estado de Guanajuato. Felipe de Jesús Calderón Hinojosa, Guanajuato, México.

21. Carranza E. (2005) Conocimiento actual de la flora y la diversidad vegetal del estado de Guanajuato, México. Flora del Bajío y Regiones Adyacentes, Fascículo complementario XXI. Instituto de Ecología, Pátzcuaro, Michoacán, México.

22. Gotelli N, Colwell R. Quantifying biodiversity: procedures and pitfalls in the measurement and comparison of species richness. Ecol Lett. 2001;4:379-91.

23. Gotelli NJ, Entsminger GL. EcoSim: Null models software for ecology, version 7. Jericho: Acquired Intelligence Inc. \& KeseyBear; 2004.

24. Martínez M. Catálogo de nombres vulgares y científicos de plantas mexicanas. México, D. F.: Fondo de Cultura Económica; 1979.

25. IPNI (2016). The International Plant Names Index http://www.ipni.org/ipni/ plantnamesearchpage.do

26. Rojas-Rabiela T, Martínez JL, Murillo D. Cultura hidráulica y simbolismo mesoamericano del agua en el México prehispánico. Jiutepec, Morelos, México: IMTA, UNESCO; 2009.

27. Schroth G, Da Fonseca GAB, Harvey CA, Gascon C, Vasconcelos HL, Izac AMN. Agroforestry and biodiversity conservation in tropical landscapes. Washington: Island Press; 2004.

28. Perfecto I, Vandermeer J. Biodiversity conservation in tropical agroecosystems: A new conservation paradigm. Ann N Y Acad Sci. 2008;1134:173-200.

29. Altieri M, Toledo VM. The agroecological revolution in Latin America: rescuing nature, ensuring food sovereignty and empowering peasants. J Peasant Stud. 2011;38:587-612.

30. COPALDEG. Programa de Desarrollo Regional: Región I Noreste. Consejo para el Desarrollo Regional Noreste. Guanajuato, México: Gobierno del Estado de Guanajuato; 2002

31. Toledo V.M. (1990). The ecological rationality of peasant production. En: Altieri M.A. y Hecth S.B. (Eds.) Agroecology and Small-farm Development, pp. 51-58, CRC Press, Boca Ratón.

32. Toledo VM, Barrera-Basolss N. La memoria biocultural: La importancia ecológica de las sabidurías tradicionales. Barcelona, España: Editorial Icaria; 2008.

\section{Submit your next manuscript to BioMed Central and we will help you at every step:}

- We accept pre-submission inquiries

- Our selector tool helps you to find the most relevant journal

- We provide round the clock customer support

- Convenient online submission

- Thorough peer review

- Inclusion in PubMed and all major indexing services

- Maximum visibility for your research

Submit your manuscript at www.biomedcentral.com/submit
) Biomed Central 